\title{
Change of Flowering and Harvest Dates of Cherry Varieties with Air Temperature
}

\author{
Hasan Cumhur Sarisu* \\ Fruit Research Institute, Egirdir, Isparta, Turkey
}

Received: 23 December 2019

Accepted: 2 May 2020

\begin{abstract}
Sweet cherry is a valuable fruit species that can generate high prices in both export and domestic market. The growth of this species includes the dates of flowering and harvesting for the management of natural risks and quality within important periods. It was examined interactions between full bloom and harvest dates of 23 different sweet cherry varieties and their orchard air temperatures in 2006-2011. The average change between the flowering dates and average of the mean daily temperatures (4.5-6.5 degrees C) is a 4-day difference with a degree temperature change. Similar correlation was found between harvest time and temperature. The time of harvest changed on average 8 days with a degree changing in the average temperature (between 8-11 degrees). In addition, among the varieties evaluated in the trial, Sunburst was determined to be the most stable variety for flowering and harvest time at temperature changes. Parallel to climate changes, the effect of temperatures on floral and harvest time changes will also affect the management of natural risks and quality. It is of great value to make feasibility studies by evaluating the climatic conditions in the growing for many years.
\end{abstract}

Keywords: Prunus avium L., cultivar, phenology, climate change, full bloom

\section{Introduction}

Global climate change has a strong impact on the living life of the planet [1-5]. It is necessary to detect and monitor this change with rapid measurable methods and to develop predictable models for its effects. Plant phenology contains very realistic data for plant response to climate change and for strong prediction modelling. Phenology is the science of repetitive events in nature [3]. Phenology also controls many aspects of vegetation by affecting different phenomena [6]. The International

*e-mail: hcumhurs@hotmail.com
Biological Program (IBP) defined phenology as "the study of the timing of recurrent biological events, the causes of their timing with regard to biotic and abiotic forces, and the interrelation among phases of the same or different species" [7]. Plant phenology is one of the important climatic components in terms of the environment. In particular, climate change caused by global warming can have serious impacts on not only for plant and animal life, but also for agricultural production, human health, tourism [8]. In terrestrial ecosystems, the impact of climate change on seasonal activity is evident and manifests itself particularly in the middle and high latitudes. One of the phenomena of high impact potential of global climate change is changes in temperatures. Temperature is the main force of many 
plant growth processes and in many cases higher temperatures accelerate plant growth. Likewise, it leads to earlier the next ontogenetic stage [3]. Vegetation phenology is very sensitive to climate change [6]. In temperate climate fruit species, phenophases are highly affected by environmental conditions. In particular, the right timing during dormancy and flowering is crucial for productivity and quality. Rapidly changing, growing environment conditions will put the future temperate climate fruit species growing at risk. Within the global changes in environmental conditions, the risks of warm winters and frosts in early spring are increasing [1]. However, it was observed that the impact of climate change on phenology was very complex and, in some places, the phenological periods in the spring were later $[9,10]$.

Cherry has an important place among the temperate climate fruit species and is one of the important species affected by global climate change. Cherry production and consumption are increasing due to the awareness of consumers about health benefits with anthocyanins and hydroxycinamic acids [11, 12]. Global cherry production, from 1997 to 2017, with the main producers of Turkey, United States and Iran has increased from 1.64 million tons to 2.44 million tons [13]. For phenology studies, it is very important to create longterm data, and therefore, cherry orchards with a long life span provide a great opportunity [14]. One of the most important indicators of spring and in most cultures in many temperate climates, cherry blossoming is of great importance. Cherry blooming time with sensitivity to winter and spring temperatures are ideal indicators of climate change in tree phenology [15].

When the temperature changes and global climate change phenology examined were found positive temperature anomalies since 1994 in Turkey. A negative correlation was found between cherry phenological periods and February-May average temperatures with high plant growth. This shows that the cherry phenological periods have shifted early in response to increasing temperatures [16].

In present study, it was investigated the effects of temperatures on cherry blooming and harvest time with 23 different standards and important commercial cherry varieties cultivated in important regions of the world have been revealed phenological periods in Egirdir ecology and the reactions of these varieties to temperature changes between years were explained.

\section{Methodology}

Plant Materials

The data collecting was carried out in the field of Eğirdir Fruit Research Institute (37\%49'12.95“N; 3052'13.73'D; $921 \mathrm{~m}$ altitude) in the years 2006-2011. Sweet cherry cultivars grafted onto Mazzard ( $P$. avium L.) seedling rootstock were planted spaced $6 \times 5 \mathrm{~m}$, in soil conditions characterized by loamy, calcareous $(12 \%$ total lime), alkaline ( $\mathrm{pH}$ 8.34). Trees were trained to a central leader and pruned in late winter and standard cultural practices. The orchards were irrigated with drip irrigation, fertilization applications were made with fertigation. In the study 23 standard sweet cherry cultivars were used.

\section{Determination of Phenological Stages of Cultivars}

The observations and yields in this study include data between 2006 and 2011 following juvenility. Phenological observations of the cultivars were made following the period of juvenility. The dates were recorded as full bloom and harvest date. The time of $70 \%$ of blooms opened was noted as full bloom dates. Fadon et al. [17] characterized the phenology of some sweet cherry varieties and adapted to 97 numerical $\mathrm{BBCH}$ codes, and framed flower development within the growth stages. According to researchers, stages (BBCH scale) were defined as follows: full bloom-stage 65. Harvest time, however, was recorded as the date when the cultivars reached harvest maturity according to stage 87 reported by Fadon et al [17].

\section{Collecting Temperature}

From 2006 to 2011, full bloom and harvest times of cherry varieties were recorded regularly. In the same period, temperatures were stored with the HOBO data logger in the trial area. In addition, validations were made with the data of the meteorology station located in the same basin as the study area and the perennial (19852011) temperature values of the region were obtained from this station. The daily average temperatures from the first day of each year (1 January) total and average temperatures to blooming and harvesting were calculated. The dates were digitized in the same way as the number of days of the year. Thus, it was determined that the cultivars bloomed and harvested on a given day.

\section{Statistical Analysis}

The experimental design was a randomized blocks, 5 replicates using a single tree. Statistical analyses were performed as regression and stability using the JMP statistical software package (vers 8; SAS Inst. Inc., Cary, NC, USA).

\section{Results and Discussion}

\section{Temperatures}

The perennial climate averages were taken from the Meteorology General Directorate station located in the same basin (Egirdir lake basin, same altitude and same 
valley) as the study area (Fig. 1). The monthly average temperature of the trial years and average temperature of each trial year are examined in Fig. 1. When the general average of the trial years is examined, it is seen that January $\left(2.14^{\circ} \mathrm{C}\right)$, February $\left(3.26^{\circ} \mathrm{C}\right)$ and March $\left(6.73^{\circ} \mathrm{C}\right)$ are warmer than the perennial averages. In contrast, April $\left(10.19^{\circ} \mathrm{C}\right)$, May $\left(14.55^{\circ} \mathrm{C}\right)$, June $\left(19.35^{\circ} \mathrm{C}\right)$ and July $\left(22.92^{\circ} \mathrm{C}\right)$ produced lower temperatures than the perennial averages. The years are compared with the individual multi-year values; In January, February of 2009, 2010 and 2011, high temperatures were observed. The lowest general average temperature in January-July period was measured in 2006 and the highest average temperature was measured in 2010. In addition, temperature fluctuations were observed to occur more frequently in January, February and March. The frequency of temperature fluctuations decreases further from April (Fig. 1). When the trial area temperature data and the multi-year temperature data of the region were compared, the average of trial years in January, February and March were higher. This has had a significant impact on the dates of bud brake and flowering in the trial area, which has an interior and passage zone ecology. The trend of the temperature is to increase in the period 1971-2012 in Turkey. The upward trend is $3.3^{\circ} \mathrm{C} /$ century and $1.3^{\circ} \mathrm{C}(14.1-12.8)$ of this has already occurred [16]. Based on the results obtained in our study, the same researchers reported high negative correlation between temperature and harvesting periods of cherry fruit for both regional and Turkey in general.

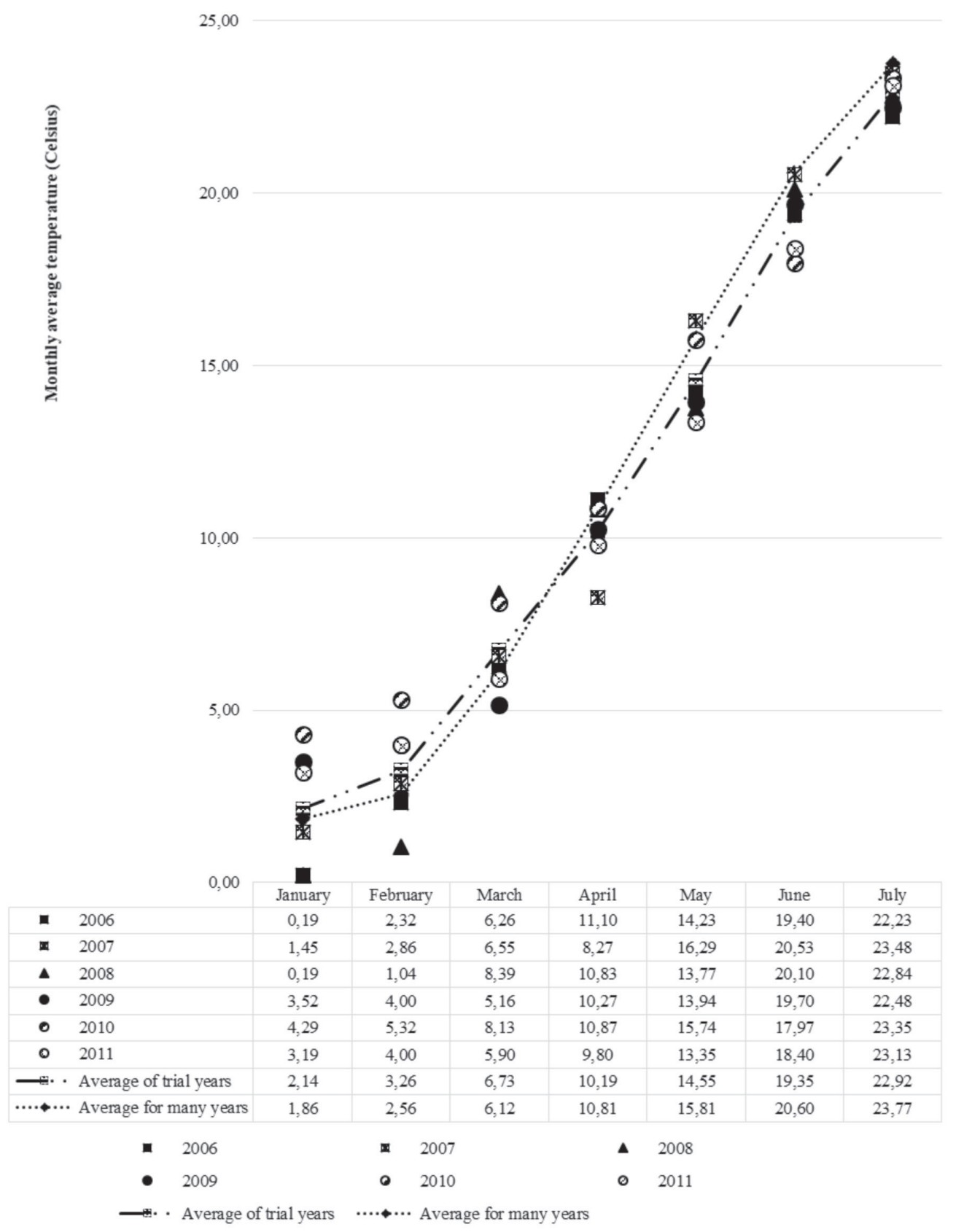

Fig. 1. The average monthly temperatures from January to July in trail years and the perennial average (1985-2011). 


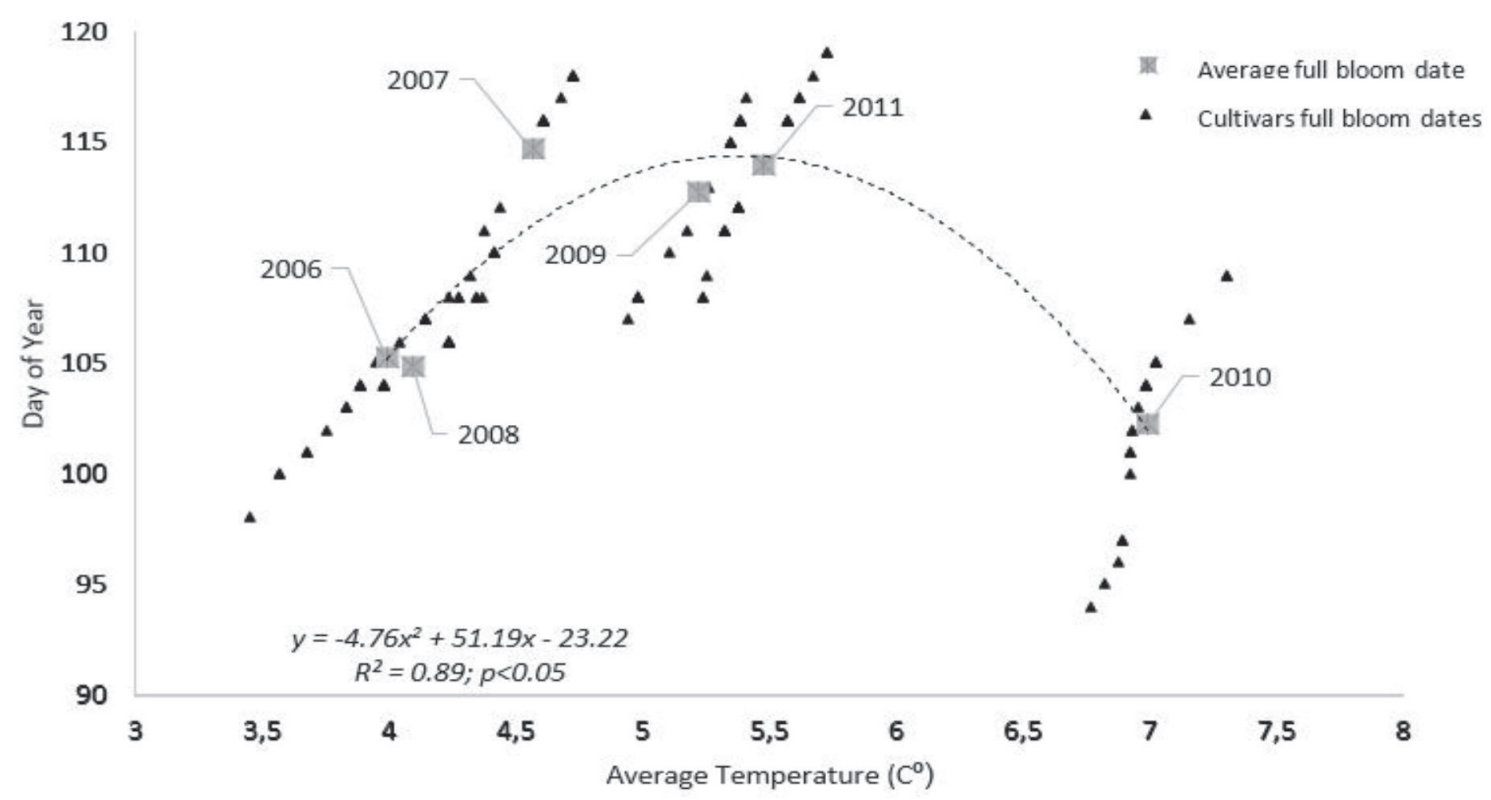

Fig. 2. Relationship between blooming dates-average and mean daily average temperatures to the dates.

\section{Flowering Dates}

The average temperature changes between $4^{\circ} \mathrm{C}$ (2006) and $7^{\circ} \mathrm{C}$ (2010) were correlated with approximately 4 days of phenological difference. The increase in the average temperatures up to $5.38^{\circ} \mathrm{C}$ delays flowering, while the higher increases suggest rapid flowering. There was a statistically significant quadratic relationship $(\mathrm{P}<0.05)$ between flowering time and mean temperatures (Fig. 2).
In addition, the rapid fluctuation of the temperature regime close to flowering affects the flowering time. Blooming dates of the varieties were recorded for six years and digitized and compared (Table 1). Among the recorded dates, the average of the varieties was determined as $102^{\text {th }}$ day in 2010 with the earliest flowering. In addition, the temperature values collected from the parcel during the observation years and the daily temperature totals that occurred until the day of the phenological period were also calculated (Table 1). The cultivars had the highest value at $715^{\circ} \mathrm{C}$ in 2010

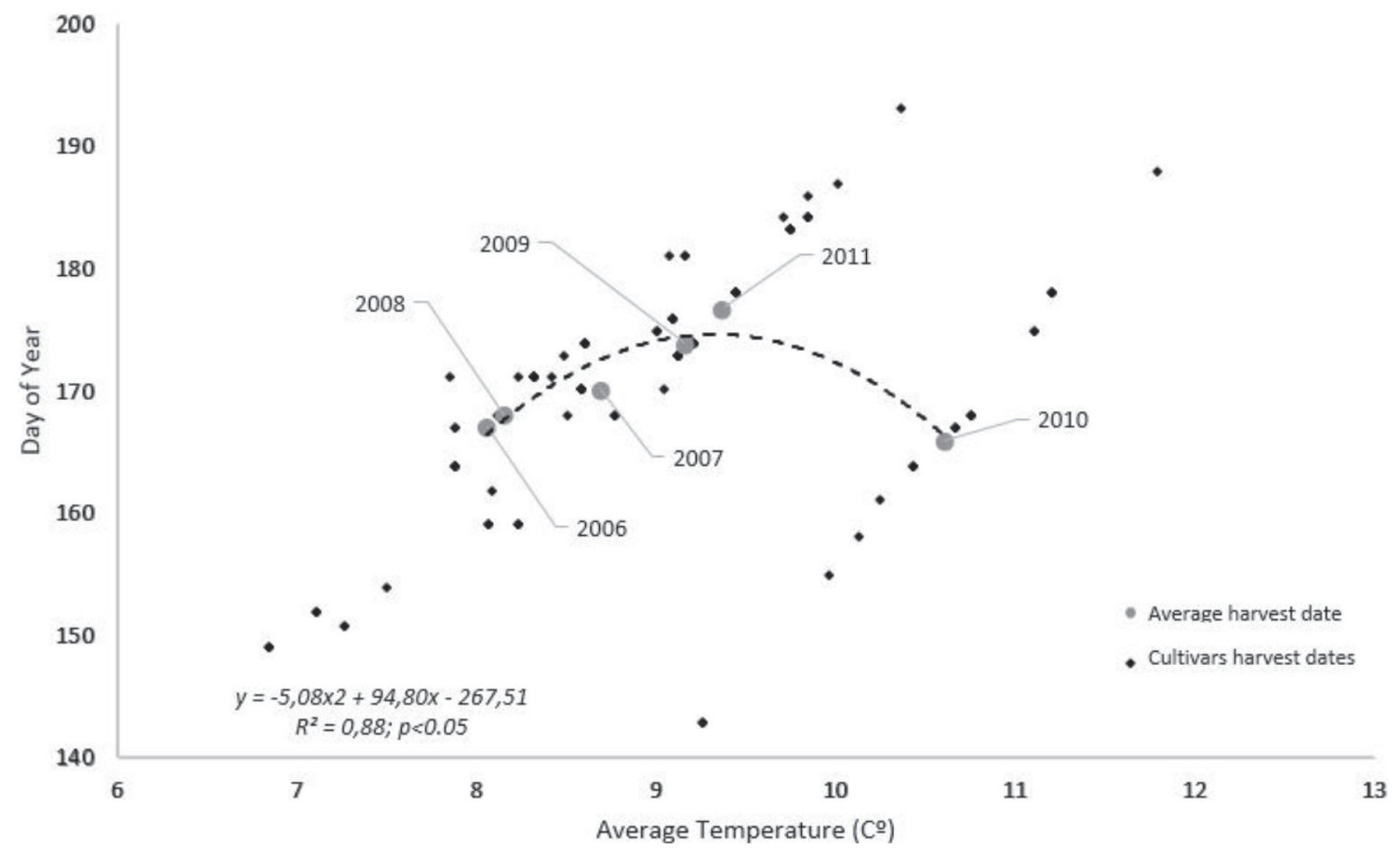

Fig. 3. Relationship between harvest dates-average and mean daily average temperatures to the dates. 
Table 1. Total daily average temperature to day of the year for full bloom and cultivars blooming dates (day of the year).

\begin{tabular}{|c|c|c|c|c|c|c|c|c|c|c|c|c|c|c|}
\hline \multirow[b]{2}{*}{ Cultivar } & \multicolumn{6}{|c|}{ Day of the year } & \multirow{2}{*}{ Av. } & \multicolumn{6}{|c|}{ Total temperatures (degree) } & \multirow{2}{*}{ Av. } \\
\hline & 2011 & 2010 & 2009 & 2008 & 2007 & 2006 & & 2011 & 2010 & 2009 & 2008 & 2007 & 2006 & \\
\hline Ferbolus & 116 & 109 & 116 & 106 & 108 & 104 & 110 & 646 & 796 & 625 & 449 & 462 & 405 & 564 \\
\hline Sweet Heart & 108 & 96 & 107 & 100 & 106 & 98 & 103 & 565 & 660 & 529 & 357 & 449 & 339 & 483 \\
\hline Veysel & 112 & 102 & 115 & 104 & 116 & 104 & 109 & 602 & 708 & 615 & 414 & 535 & 405 & 546 \\
\hline Octavia & 119 & 104 & 116 & 104 & 118 & 108 & 112 & 682 & 727 & 625 & 414 & 558 & 471 & 580 \\
\hline Celeste & 116 & 103 & 113 & 106 & 116 & 108 & 110 & 646 & 716 & 595 & 449 & 535 & 457 & 566 \\
\hline Rainier & 112 & 101 & 108 & 104 & 109 & 104 & 106 & 602 & 699 & 539 & 414 & 471 & 405 & 522 \\
\hline $\begin{array}{l}\text { Mechlain } \\
\text { Haimer }\end{array}$ & 112 & 105 & 115 & 106 & 116 & 107 & 110 & 602 & 738 & 615 & 449 & 535 & 443 & 564 \\
\hline Techlovan & 111 & 101 & 111 & 104 & 116 & 104 & 108 & 591 & 699 & 575 & 414 & 535 & 405 & 536 \\
\hline Sunburst & 116 & 105 & 116 & 104 & 116 & 107 & 111 & 646 & 738 & 625 & 414 & 535 & 443 & 567 \\
\hline Cultivar 7 & 114 & 102 & 110 & 106 & 116 & 104 & 109 & 624 & 708 & 562 & 449 & 535 & 405 & 547 \\
\hline Silvia & 114 & 105 & 116 & 108 & 116 & 101 & 110 & 624 & 738 & 625 & 469 & 535 & 372 & 561 \\
\hline Cultivar 3 & 117 & 104 & 116 & 108 & 118 & 106 & 112 & 657 & 727 & 625 & 469 & 558 & 429 & 578 \\
\hline Venüs & 109 & 95 & 108 & 104 & 111 & 104 & 105 & 573 & 648 & 539 & 414 & 486 & 405 & 511 \\
\hline Lapins & 108 & 97 & 108 & 104 & 108 & 101 & 104 & 565 & 668 & 539 & 414 & 462 & 372 & 503 \\
\hline Glacier & 116 & 104 & 117 & 106 & 118 & 110 & 112 & 646 & 727 & 633 & 449 & 558 & 405 & 570 \\
\hline Summit & 116 & 104 & 116 & 104 & 116 & 107 & 111 & 646 & 727 & 625 & 414 & 535 & 443 & 565 \\
\hline Fercair & 111 & 100 & 108 & 106 & 116 & 103 & 107 & 591 & 693 & 495 & 449 & 535 & 395 & 526 \\
\hline P.de Bernard & 111 & 94 & 108 & 100 & 112 & 102 & 105 & 591 & 637 & 539 & 357 & 497 & 383 & 501 \\
\hline Belge & 117 & 107 & 116 & 106 & 116 & 110 & 112 & 657 & 766 & 625 & 449 & 535 & 486 & 586 \\
\hline Kordia & 118 & 109 & 116 & 106 & 118 & 103 & 112 & 669 & 796 & 625 & 449 & 558 & 395 & 582 \\
\hline 0900 Ziraat & 119 & 104 & 116 & 106 & 118 & 110 & 112 & 682 & 727 & 625 & 449 & 558 & 486 & 588 \\
\hline Star & 112 & 97 & 108 & 104 & 116 & 105 & 107 & 602 & 668 & 539 & 414 & 535 & 415 & 529 \\
\hline N.de Meched & 116 & 104 & 115 & 106 & 117 & 110 & 111 & 646 & 727 & 615 & 449 & 547 & 486 & 578 \\
\hline Average & 114 & 102 & 113 & 105 & 115 & 105 & & 624 & 715 & 589 & 429 & 524 & 420 & \\
\hline
\end{tabular}

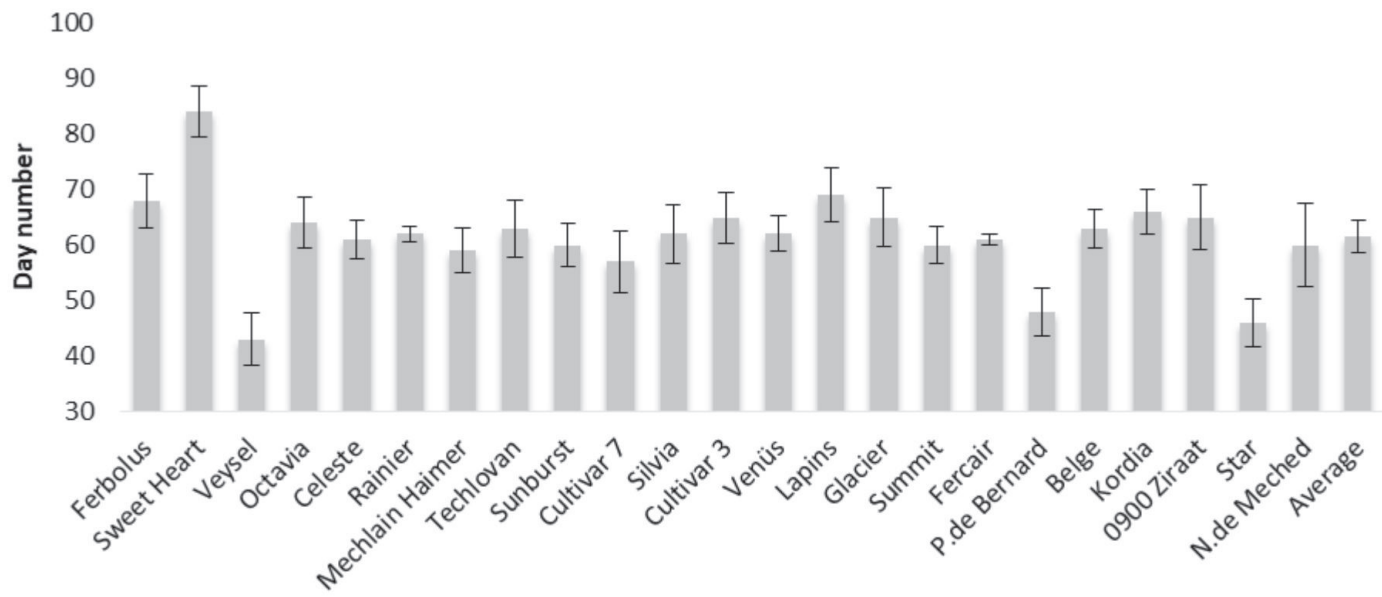

Cultivars

Fig. 4. The mean days numbers of cherry cultivars between blooming and harvest dates ( $\pm \mathrm{SD})$. 
Table 2. Total daily average temperature to day of the year for harvest and cultivars harvest dates (day of the year).

\begin{tabular}{|c|c|c|c|c|c|c|c|c|c|c|c|c|c|c|}
\hline \multirow[b]{2}{*}{ Cultivar } & \multicolumn{6}{|c|}{ Day of the year } & \multirow{2}{*}{ Av. } & \multicolumn{6}{|c|}{ Total temperatures (degree) } & \multirow{2}{*}{ Av. } \\
\hline & 2011 & 2010 & 2009 & 2008 & 2007 & 2006 & & 2011 & 2010 & 2009 & 2008 & 2007 & 2006 & \\
\hline Ferbolus & 184 & 178 & 183 & 181 & 175 & 164 & 178 & 1784 & 1991 & 1783 & 1656 & 1574 & 1288 & 1679 \\
\hline Sweet Heart & 193 & 188 & 187 & 181 & 186 & 181 & 186 & 1998 & 2213 & 1868 & 1656 & 1829 & 1640 & 1867 \\
\hline Veysel & 159 & 143 & 159 & 149 & 151 & 152 & 152 & 1307 & 1323 & 1282 & 1017 & 1097 & 1077 & 1184 \\
\hline Octavia & 178 & 168 & 183 & 174 & 176 & 171 & 175 & 1681 & 1804 & 1783 & 1496 & 1599 & 1435 & 1633 \\
\hline Celeste & 178 & 167 & 173 & 167 & 170 & 171 & 171 & 1681 & 1780 & 1574 & 1339 & 1458 & 1421 & 1542 \\
\hline Rainier & 174 & 164 & 168 & 167 & 170 & 164 & 168 & 1599 & 1707 & 1471 & 1339 & 1458 & 1288 & 1477 \\
\hline Mechlain Haimer & 178 & 164 & 173 & 167 & 170 & 164 & 169 & 1681 & 1707 & 1574 & 1339 & 1534 & 1288 & 1521 \\
\hline Techlovan & 178 & 168 & 173 & 167 & 170 & 171 & 171 & 1680 & 1804 & 1574 & 1313 & 1458 & 1421 & 1542 \\
\hline Sunburst & 178 & 167 & 173 & 167 & 170 & 171 & 171 & 1681 & 1780 & 1574 & 1313 & 1458 & 1421 & 1538 \\
\hline Cultivar 7 & 174 & 158 & 168 & 167 & 162 & 164 & 166 & 1599 & 1596 & 1471 & 1339 & 1309 & 1288 & 1434 \\
\hline Silvia & 178 & 167 & 173 & 167 & 176 & 173 & 172 & 1681 & 1780 & 1574 & 1339 & 1599 & 1465 & 1573 \\
\hline Cultivar 3 & 178 & 175 & 183 & 174 & 176 & 171 & 176 & 1681 & 1942 & 1783 & 1496 & 1599 & 1421 & 1654 \\
\hline Venüs & 174 & 155 & 168 & 167 & 170 & 171 & 168 & 1599 & 1544 & 1471 & 1339 & 1458 & 1405 & 1469 \\
\hline Lapins & 184 & 168 & 173 & 174 & 170 & 171 & 173 & 1807 & 1804 & 1574 & 1496 & 1458 & 1421 & 1593 \\
\hline Glacier & 184 & 175 & 183 & 174 & 175 & 171 & 177 & 1807 & 1942 & 1783 & 1496 & 1574 & 1340 & 1657 \\
\hline Summit & 178 & 164 & 173 & 167 & 170 & 168 & 170 & 1681 & 1707 & 1574 & 1339 & 1458 & 1360 & 1520 \\
\hline Fercair & 174 & 161 & 168 & 167 & 176 & 164 & 168 & 1599 & 1647 & 1427 & 1339 & 1599 & 1288 & 1483 \\
\hline P.de Bernard & 159 & 143 & 159 & 149 & 151 & 152 & 152 & 1307 & 1323 & 1282 & 1017 & 1097 & 1077 & 1184 \\
\hline Belge & 178 & 168 & 183 & 174 & 176 & 171 & 175 & 1681 & 1804 & 1783 & 1496 & 1599 & 1421 & 1631 \\
\hline Kordia & 184 & 178 & 183 & 174 & 176 & 171 & 178 & 1807 & 1991 & 1783 & 1496 & 1599 & 1421 & 1683 \\
\hline 0900 Ziraat & 184 & 178 & 183 & 174 & 175 & 171 & 178 & 1807 & 1991 & 1783 & 1496 & 1574 & 1421 & 1679 \\
\hline Star & 159 & 143 & 159 & 149 & 154 & 152 & 153 & 1307 & 1323 & 1282 & 1017 & 1154 & 1077 & 1193 \\
\hline N.de Meched & 178 & 178 & 173 & 167 & 170 & 164 & 172 & 1681 & 1991 & 1574 & 1339 & 1458 & 1288 & 1555 \\
\hline Average & 177 & 166 & 174 & 168 & 170 & 167 & & 1658 & 1760 & 1593 & 1370 & 1478 & 1347 & \\
\hline
\end{tabular}

at the total daily temperatures that occurred until the flowering period. In 2006 and 2008, the average of blooming at the $105^{\text {th }}$ day was from the early flowering date and the temperature totals were $420^{\circ} \mathrm{C}$ and $429^{\circ} \mathrm{C}$ respectively (Table 1). This contrasting situation is actually the sudden high temperatures in April $\left(11.10^{\circ} \mathrm{C}\right)$ for 2006 and March $\left(8.39^{\circ} \mathrm{C}\right)$ for 2008 (Fig. 1). The low temperatures in the months of the other temperatures totalled the low overall temperature. In 2006 and 2008, before flowering, the sudden increase in temperature was thought to trigger the flowering rate.

Fluctuations up to 15 days were observed in some cultivars during the experimental years. The average temperature changes between $4^{\circ} \mathrm{C}(2006)$ and $7^{\circ} \mathrm{C}$ (2010) were correlated with approximately 4 days of difference and there was a statistically significant quadratic relationship between flowering time and mean temperatures. A temperature change of one degree caused an 8-day change in the average harvest dates of the varieties. According to the researchers, the predictions in foliation and flowering for forest and fruit trees were 1.9 to 7.7 days per ${ }^{\circ} \mathrm{C}(2,18,19]$. The flowering of early-ripening cherry varieties in Germany has improved by 4.7 days $/{ }^{\circ} \mathrm{C}[2,20]$. In addition, due to the warmer winter, cherry production in South-West France was significantly affected and in 2007 it resulted in $30 \%$ yield [21, 22]. Sarısu [23] found, in his study that correlates temperatures and fruit set, that when the average temperature between bud burst and petal fall increased by $1^{\circ} \mathrm{C}$, it reduced fruit set by about $4 \%$ in trial years. Different researchers have reported that warmer winters may cause delayed spring phenology for some species and occasionally cause abnormal flowering phenology and low productivity [21, 22]. 
Table 3 . The average total daily temperatures between blooming and harvest dates.

\begin{tabular}{|c|c|c|c|c|c|c|c|}
\hline \multirow{2}{*}{ Cultivar } & \multicolumn{7}{|c|}{ Total temperatures (degree; Fub to Harvest) } \\
\hline & 2011 & 2010 & 2009 & 2008 & 2007 & 2006 & Average \\
\hline Ferbolus & 1138 & 1194 & 1158 & 1207 & 1112 & 883 & 1115 \\
\hline Sweet Heart & 1433 & 1552 & 1339 & 1299 & 1380 & 1301 & 1384 \\
\hline Veysel & 705 & 615 & 666 & 603 & 562 & 672 & 637 \\
\hline Octavia & 999 & 1077 & 1158 & 1082 & 1041 & 964 & 1053 \\
\hline Celeste & 1035 & 1064 & 979 & 890 & 923 & 964 & 976 \\
\hline Rainier & 998 & 1007 & 933 & 925 & 987 & 883 & 955 \\
\hline $\begin{array}{c}\text { Mechlain } \\
\text { Haimer }\end{array}$ & 1079 & 969 & 959 & 890 & 999 & 845 & 957 \\
\hline Techlovan & 1089 & 1104 & 1000 & 899 & 923 & 1016 & 1005 \\
\hline Sunburst & 1035 & 1041 & 949 & 899 & 923 & 978 & 971 \\
\hline Cultivar 7 & 976 & 888 & 910 & 890 & 774 & 883 & 887 \\
\hline Silvia & 1057 & 1041 & 949 & 870 & 1064 & 1093 & 1012 \\
\hline Cultivar 3 & 1024 & 1215 & 1158 & 1027 & 1041 & 992 & 1076 \\
\hline Venüs & 1026 & 895 & 933 & 925 & 972 & 1000 & 958 \\
\hline Lapins & 1242 & 1135 & 1036 & 1082 & 996 & 1049 & 1090 \\
\hline Glacier & 1161 & 1215 & 1150 & 1047 & 1016 & 935 & 1087 \\
\hline Summit & 1035 & 980 & 949 & 925 & 923 & 917 & 955 \\
\hline Fercair & 1009 & 954 & 933 & 890 & 1064 & 893 & 957 \\
\hline P.de Bernard & 716 & 686 & 743 & 660 & 600 & 694 & 683 \\
\hline Belge & 1024 & 1037 & 1158 & 1047 & 1064 & 935 & 1044 \\
\hline Kordia & 1138 & 1194 & 1158 & 1047 & 1041 & 1026 & 1101 \\
\hline 0900 Ziraat & 1125 & 1264 & 1158 & 1047 & 1016 & 935 & 1091 \\
\hline Star & 705 & 654 & 743 & 603 & 619 & 662 & 664 \\
\hline N.de Meched & 1035 & 1264 & 959 & 890 & 911 & 802 & 977 \\
\hline Average & 1034 & 1046 & 1003 & 941 & 954 & 927 & \\
\hline
\end{tabular}

\section{Harvest Dates}

A temperature change of one degree between average temperatures until the average harvest date in $2006\left(8.07^{\circ} \mathrm{C}\right)$ and $10.60^{\circ} \mathrm{C}$ in 2010 caused an 8-day change in the average harvest dates of the varieties (Fig. 3). 45-day harvest time difference was found between the earliest ripening (Star; $143^{\text {th }}$ day of the year) and the latest ripening cultivar (Sweet Heart; $188^{\text {th }}$ day of the year) in 2010. This difference was 29 days in 2006 with the lowest average temperature (Table 2). In general, the order of harvest time between the varieties did not change, but the difference between harvest times was highly affected by the temperature regime.

The year in which the varieties were harvested on average was 2011 with an average of 177 days. The most important factor determining this situation was thought to be the low temperatures in April and
May. 2010, 2008 and 2006 were determined as the years of early ripening of varieties. It was interpreted that harvest time was prominent with the high temperature sum of 2010, high April temperatures of 2006 and high temperatures of March, April and May of 2008 (Table 2, Fig. 1).

In the study, it was concluded that the duration between the flowering and harvest were affected by the conditions of the phenophase. Usenik and Stampar [24] found that significantly higher average temperatures in April and May shortened the fruit development period for 7 days in Burlat and 11 days for Germersdorfer. These findings of the researchers support the study that the temperature conditions occurring during fruit development may affect the development process. In addition, the data obtained from our study showed that the responses of the varieties to temperature changes could be different. 


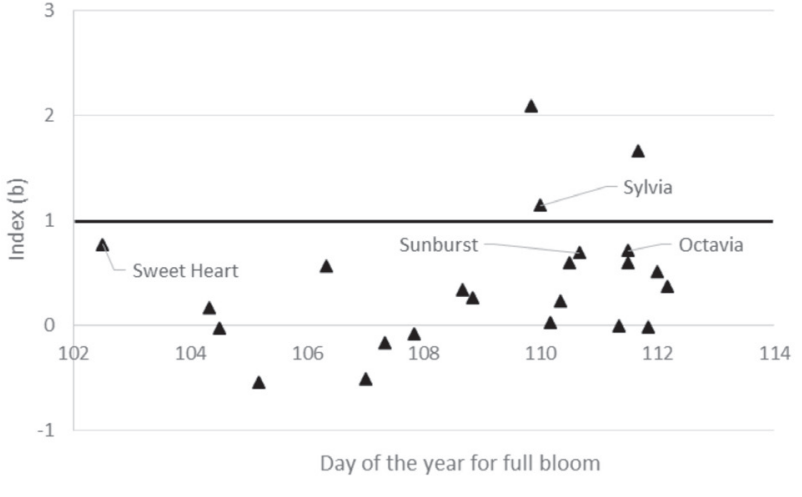

Fig. 5. Stability of varieties in terms of flowering dates.

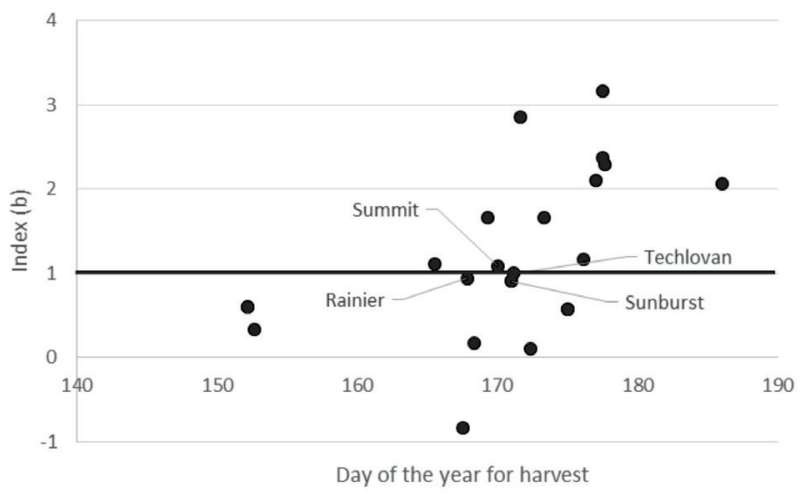

Fig. 6. Stability of varieties in terms of harvest dates.

\section{Duration from Flowering to Harvest}

The period from flowering to harvest is one of the important indicators in cherry growing. In addition, climatic events that occur to the production of the basic crop (harvest) from the start of vegetation (full bloom) are important in terms of both productivity and quality. For this reason, the temperature totals from flowering to harvest and the responses of the varieties were evaluated. The year 2010, which had the longest duration with an average of 64 days (Fig. 4), also had the highest total temperature (Table 3). There seems to be an opposite relationship, and was thought to be due to extremely low June temperatures (Fig. 1). In addition, it can be said that the harvest dates of the 2010 varieties spread over time and the gap between them was quite wide. In 2007, when flowering to harvest was the shortest (56 days; Fig. 4), the temperature total was relatively low $\left(954^{\circ} \mathrm{C}\right)$. It may seem that this may explain the condition exceptionally low $\left(8.27^{\circ} \mathrm{C}\right)$, May $\left(16.29^{\circ} \mathrm{C}\right)$ and June $\left(20.53^{\circ} \mathrm{C}\right)$ were extremely high.

\section{Cultivar Stability}

Stability analysis was applied on flowering and harvesting dates to determine how the varieties reacted to temperature differences during the trial years and to determine the least responsive varieties. Sylvia, Octavia,
Sweet Heart and Sunburst are the least stable varieties that show the least variation from year to year in terms of flowering dates (Fig. 5). Summit, Techlovan, Rainier and Sunburst varieties were the most stable varieties in temperature changes at harvest times (Fig. 6).

The Sunburst cherry variety, which is common in both data analyses, was determined as the most stable cherry cultivar in terms of temperature changes from year to year in terms of both flowering and harvest date.

In this study, the stability analysis of the varieties have been revealed to give more stable reactions over the years. Wenden and Mariadassou [1], attaches importance to strategies to anticipate the changes needed in agriculture and to grow new varieties that are better adapted to future climatic conditions. In our study, the reactions of the cultivars during the experiment were analyzed for stability and it was determined that Sunburst cultivar behaved more stable than the others in terms of harvest and flowering time. For this reason, it is important to make more genetic studies on varieties such as Sunburst and to take part in breeding studies. The speed of the cherry phenological process is influenced by the temperature of the previous months. The shortening of fruit development time will likely reduce cherry fruit quality and yield, but earlier flowering after warmer winter will increase the risk of spring frosts [24]. Such changes can threaten temperate fruit production and therefore affect the global economy [1].

\section{Conclusions}

As a result, it can be said that the temperature changes occurring for long years in the temperate climate regions can have significant effects on the phenology of the species and even the varieties that will occur between the phenophases. It is thought that a 1 degree change in the average temperatures until flowering can cause 4-day flowering and 8-day harvest time shifts in species average and these changes will have negative effects on yield and quality. Therefore, more studies are needed to highlight the species and varieties that react less to change. In this study, Sunburst variety was found to be the least responsive to temperature change. It was concluded that it would be important to examine this character and use it in breeding programs.

\section{Acknowledgements}

This work was supported by Republic of Turkey Ministry of Agriculture and Forestry General Directorate of Agricultural Research and Policies.

\section{Conflict of Interest}

The authors declare no conflict of interest. 


\section{References}

1. WENDEN B., MARIADASSOU M. Sweet cherry phenology in the context of climate change: a systems biology approach. Acta Hortic. 1162, 31, 2017.

2. JOCHNER S., SPARKS T.H., LAUBE J., MENZEL A. Can we detect a nonlinear response to temperature in European plant phenology? Int. J. Biometeorol. 60, 1551, 2016.

3. BADECK F., BONDEAU A., BÖTTCHER K., DOKTOR D., LUCHT W., SCHABER J., SITCH S. Responses of spring phenology to climate change. New Phytologist, 162, 295, 2004.

4. PARMESAN C., YOHE G. A globally coherent fingerprint of climate change impacts across natural systems. Nature, 421 (6918), 37, 2003.

5. ROOT T., PRICE J., HALL K., SCHNEIDER S., ROSENZWEIG C., POUNDS A. Fingerprints of global warming on wild animals and plants. Nature, 421 (6918), 57, 2003.

6. RICHARDSON A.D., KEENAN T.F., MIGLIAVACCA M., RYU Y., SONNENTAG O., TOOMEY M. Climate change, phenology, and phenological control of vegetation feedbacks to the climate system. Agricultural and Forest Meteorology, 169, 156, 2013.

7. LIETH H. Phenology and Seasonality Modeling. Springer Verlag, Berlin, 444 pp. 1974.

8. YOSHINO M., ONO H.S.P. Variations in the Plant Phenology Affected by Global Warming. In: Climate Change and Plants in East Asia. Springer, Tokyo, 93, 1996.

9. ATKINSON C.J., BRENNAN R.M., JONES H.G. Declining chilling and its impact on temperate perennial crops. Environmental and Experimental Botany. 91, 48, 2013.

10. ELLOUMI O., GHRAB M., KESSENTINI H., BEN MIMOUN M. Chilling accumulation effects on performance of pistachio trees cv. Mateur in dry and warm area climate. Scientia Horticulturae, 159, 80, 2013.

11. BLANDO F., OOMAH B.D. Sweet and sour cherries: Origin, distribution, nutritional composition and health benefits, Trends in Food Science \& Technology, 86, 517, 2019.

12. ÖNEM E. Sourcherry and human Health. Fruit Science (Meyve Bilimi), 4 (2), 1, 2017.

13. FAO. The Food and Agriculture Organization (FAO). http://www.fao.org/faostat. (accessed on 23.12.2019).

14. WENDEN B., CAMPOY J.A., LECOURT J., LÓPEZ ORTEGA G., BLANKE M., RADIČEVIĆ S., SCHÜLLER
E., SPORNBERGER A., CHRISTEN D., MAGEIN H., GIOVANNINI D., CAMPILLO C., MALCHEV S., PERIS J.M., MELAND M., STEHR R., CHARLOT G., QUEROGARCÍA J. A collection of European sweet cherry phenology data for assessing climate change. Sci Data. Dec 6 (3), 160108, 2016.

15. CHUNG U., MACK L., YUN J.I., KIM S.H. Predicting the Timing of Cherry Blossoms in Washington, DC and Mid-Atlantic States in Response to Climate Change. PLoS ONE, 6 (11), e27439, 2011.

16. TÜRKOĞLU N., ŞENSOY S., AYDIN O. Effects of climate changes on phenological periods of apple, cherry and wheat in Turkey. International Journal of Human Sciences, 13(1), 1036. doi.org/10.14687/ijhs.v13i1.3464, 2016.

17. FADÓN E, HERRERO M., RODRIGO J. Flower development in sweet cherry framed in the BBCH scale. Scientia Horticulturae, 192, 141, 2015.

18. MENZEL A., SPARKS T. H., ESTRELLA N., KOCH E., AASA A., AHAS R., ZUST A. European phenological response to climate change matches the warming pattern. Global Change Biology, 12 (10), 1969, 2006.

19. WOLKOVICH E.M., COOK B.I., ALLEN J.M., CRIMMINS T.M., BETANCOURT J.L., TRAVERS S.E., PAU S., REGETZ J., DAVIES T.J., KRAFT N.J.B., AULT T.R., BOLMGREN K., MAZER S.J., MCCABE G.J., MCGILL B.J., PARMESAN C., SALAMIN N., SCHWARTZ M.D., CLELAND E.E. Warming experiments underpredict plant phenological responses to climate change. Nature, 485 (7399), 494, 2012.

20. CHMIELEWSKI F.M., MÜLLER A., BRUNS E. Climate changes and trends in phenology of fruit trees and field crops in Germany, 1961-2000. Agric. For. Meteorol. 121, 69, 2004.

21. DOI H., GORDO O., KATANO I. Heterogeneous intraannual climatic changes drive different phenological responses at two trophic levels. Clim. Res. 36, 181, 2008

22. COOK B.I., WOLKOVICH E.M., PARMESAN C. Divergent responses to spring and winter warming drive community level flowering trends. Proc. Natl. Acad. Sci. USA, 109, 9000, 2012.

23. SARISU H.C. Effect of high temperatures during blooming on sweet cherry fruit set. Derim, 34 (2), 85, 2017.

24. USENIK V., ŠTAMPAR F. The Effect of Environmental Temperature on Sweet Cherry Phenology. Europ.J.Hort. Sci., 76 (1), 1, 2011. 
